\title{
MENINGKATKAN HASIL BELAJAR SISWA MELALUI MODEL PEMBELAJARAN KOOPERATIF TIPE STAD (STUDENT TEAMS ACHIEVEMENT DIVISIONS) DI KELAS IV SDN 1 PUURAU
}

\author{
Syamsidar ${ }^{1)}$, Izlan Sentryo ${ }^{2)}$ \\ 1) SDN 1 Puurau, Kolaka Utara, Indonesia \\ ${ }^{2)}$ Jurusan PGSD, Universitas Halu Oleo, Kendari, Indonesia \\ email: syamsidar.pji@gmail.com
}

\begin{abstract}
Abstrak: Tujuan penelitian ini adalah untuk meningkatkan hasil belajar matematika siswa pada materi pokok Pengukuran di Kelas IV SD Negeri 1 Puurau Kabupaten Kolaka Utara melalui model pembelajaran Kooperatif tipe STAD. Jenis penelitian ini adalah penelitian tindakan kelas. Prosedur penelitian ini adalah (1) perencanaan, (2) pelaksanaan tindakan, (3) observeasi dan evaluasi, (4) refleksi. Sumber data dalam penelitian ini adalah guru dan siswa. Jenis data yang diperoleh adalah data kualitatif dan data kuantitas yang terdiri atas lembar observasi, tes hasil belajar dan jurnal. Hasil penelitian menunjukkan hasil belajar siswa pada siklus I tentang materi pokok Pengukuran presentase ketuntasan mencapai 57,14 \%. Dan setelah dilakukan tindakan maka presentase ketuntasan mencapai 90,47 \%. Demikian pula hasil observasi guru dan siswa terhadapa pelaksanaan tindakan, presentase pelaksanaan tindakan menunjukkan peningkatan yaitu pada siklus I hasil observasi guru sebesar $85,83 \%$ dan meningkat pada siklus II sebesar $81,67 \%$. Sementara hasil observasi siswa terhadap pelaksanaan tindakan pada siklus I yaitu 63,39\% dan meningkat pada siklus II yaitu $85,71 \%$. Hal ini menunjukkan bahwa indikator keberhasilan yang ditetapkan pada indikator kinerja sudah tercapai pada siklus II, atau dapat disimpulkan bahwa ketuntasan belajar siswa dapat tercapai.

Kata Kunci: model pembelajaran kooperatif tipe stad; hasil belajar
\end{abstract}

\section{IMPROVING THE STUDENT'S LEARNING OUTCOMES THROUGH THE STAD TYPE COOPERATIVE LEARNING MODEL (STUDENT TEAMS ACHIEVEMENT DIVISIONS) IN CLASS IV SDNI 1 PUURAU}

\begin{abstract}
The purpose of this research was to improve student mathematics learning outcomes on the subject matter of Measurement in Class IV SD Negeri 1 Puurau, Kolaka Utara Regency through the STAD cooperative learning model. This type of research is classroom action research. The procedures for this research are (1) planning, (2) implementing actions, (3) observing and evaluating, (4) reflecting. The data sources in this study were teachers and students. The types of data obtained are qualitative data and quantity data consisting of observation sheets, learning outcomes tests and journals. The results showed that student learning outcomes in the first cycle about the subject matter of measuring the percentage of completeness reached $57.14 \%$. And after taking the action, the percentage of completeness reached $90.47 \%$. Likewise, the results of teacher and student observations on the implementation of the action, the percentage of the implementation of the action showed an increase, namely in the first cycle the teacher's observation results were $85.83 \%$ and increased in the second cycle by $81.67 \%$. Meanwhile, the results of student observations on the implementation of the action in the first cycle were $63.39 \%$ and increased in the second cycle, namely $85.71 \%$. This shows that the success indicators set on the performance indicators have been achieved in cycle II, or it can be concluded that students' learning completeness can be achieved.
\end{abstract}

Keywords: stad type cooperative learning model; learning outcomes 


\section{Pendahuluan}

Dalam rangka mencerdaskan kehidupan bangsa, maka peningkatan mutu pendidikan suatu hal yang sangat penting bagi pembangunan berkelanjutan di segala aspek kehidupan manusia. Pada saat ini, bidang pendidikan mengalami perubahan ke arah yang lebih baik dari saat-saat sebelumnya. Hal ini dapat dilihat dari semakin besarnya kesadaran masyarakat akan pentingnya pendidikan, selain itu dapat dilihat pula dari kepedulian pemerintah dalam pembiayaan kegiatan operasional di sekolah dengan dikucurkannya dana BOS (Biaya Operasional Sekolah) bagi setiap sekolah. Hal ini disebabkan oleh mulai timbulnya kesadaran dari sebagian besar masyarakat dan Pemerintah bahwa pendidikan merupakan suatu cara pembentukan kemampuan dan karakter manusia dalam rangka menciptakan sumber daya manusia yang berkualitas dalam menunjang pembangunan bangsa.

Dengan perkembangan ilmu pengetahuan dan teknologi yang semakin pesat, maka peran guru pelajaran Matematika agar senantiasa meningkatkan keterampilan dan kualitas intelektual didalam kegiatan pembelajaran, bahkan guru pelajaran Matematika perlu tampil disetiap kesempatan baik sebagai pendidik, pengajar, pelatih, inovator, fasilisator maupun sebagai dinamisator dengan cara menerapkan model pembelajaran Matematika yang variatif. Matematika selain sebagai salah satu bidang dalam dunia pendidikan juga merupakan salah satu bidang studi yang sangat penting, baik bagi peserta didik maupun bagi pengembangan bidang keilmuan yang lain. Matematika adalah ilmu deduktif, artinya setiap proses pencarian kebenaran dalam matematika dilakukan melalui cara deduktif dan berbeda dengan ilmu pengetahuan lainnya yang didasarkan pada cara induktif (Indah, 2015, p.16).

Untuk mengatasi permasalahan tersebut, diperlukan suatu model pembelajaran yang lebih tepat dan menarik, dimana siswa dapat belajar secara berkelompok, dapat bertanya meskipun tidak pada guru secara langsung, dan mengemukakan pendapat. Salah satu upaya untuk meningkatkan hasil belajar siswa adalah dengan menerapkan model pembelajaran kooperatif. Pembelajaran kooperatif merupakan salah satu cara yang digunakan guru untuk mengatasi masalah di atas. Dalam hal ini, pembelajaran kooperatif dapat diterapkan agar siswa benar-benar menerima ilmu dari pengalaman belajar bersama temannya, baik yang sudah dikatakan cakap maupun yang masih dikatakan lemah dalam memahami konsep atau materi pelajaran. Salah satu ciri dalam pembelajaran kooperatif, adalah adanya pembagian kelompok belajar yang diarahkan untuk mencapai keberhasilan dalam menguasai suatu konsep yang diajarkan. Mulyasa (2009, p.172) mengatakan, untuk meningkatkan kualitas pembelajaran, guru harus mampu membangkitkan motivasi belajar peserta didik sehingga dapat mencapai tujuan pembelajaran. Setiap guru sebaiknya memiliki rasa ingin tahu, mengapa dan bagaimana anak belajar dan menyesuaikan dirinya dengan kondisi-kondisi belajar dalam lingkungannya. Selanjutnya Hamalik dalam Suhardi, dkk. (2014:28) "belajar adalah modifikasi atau memperteguh kelakuan melalui pengalaman (learning is defined as the modification strengtheining of bohavior thourgh experiencing)".

Sejumlah tipe model pembelajaran kooperatif yang telah diterapkan di kelas dalam upaya untuk meningkatkan hasil belajar siswa, salah satu diantaranya adalah model pembelajaran koperatif tipe STAD. Pembelajaran model ini lebih meningkatkan kerja sama antar siswa. Siswa-siswa terbagi dalam beberapa kelompok belajar dan bekerja sama dalam suatu perencanaan kegiatan. STAD didesain untuk meningkatkan rasa tanggung jawab siswa terhadap pembelajarannya sendiri dan juga pembelajaran orang lain, sehingga dengan model ini, siswa akan lebih mudah memecahkan masalah Matematika dan diharapkan dapat meningkatkan hasil belajar siswa. Menurut Lie dalam Dewi, (2016, p.5) mengemukakan bahwa model pembelajaran kooperatif tipe NHT (Numbered Head Together) memberi kesempatan kepada siswa untuk membagikan ide-ide dan mempertimbangkan jawaban yang paling tepat serta mendorong siswa untuk meningkatkan semangat kerjasama mereka. Model 
ini memungkinkan siswa terlibat aktif dalam kegiatan pembelajaran karena siswa akan terbentuk dalam satu kelompok yang terstruktur dalam melaksanakan proses pembelajaran. Siswa dapat saling membantu satu sama lain dan memiliki tanggung jawab baik secara bersama-sama maupun secara sendiri dalam menuntaskan pembelajaran. Melalui pembelajaran kooperatif tipe NHT diharapkan memberikan suasana baru dalam kinerja guru IPS, mengoptimalkan aktivitas belajar siswa sehingga pada akhirnya hasil belajar IPS siswa juga akan meningkat. Metode NHT menuntut siswa untuk mampu bertanggungjawab baik secara individu maupun kelompok. Pembelajaran dengan metode NHT menuntut siswa untuk bisa menjawab pertanyaan ketika nomornya dipanggil secara acak oleh peneliti, dimana hal ini dapat menjadi motivasi bagi siswa karena poin yang diperoleh tidak hanya untuk siswa itu sendiri tetapi sekaligus perolehan bagi kelompoknya (Permana, 2016, p.51). Arsini (2015, p.3) Pada model pembelajaran NHT ini siswa dikelompokkan menjadi beberapa kelompok yang beranggotakan 4-6 orang secara heterogen. Sehingga, model pembelajaran ini memungkinkan siswa untuk bekerjasama dan bertukar pikiran untuk menyelesaikan suatu masalah yang diberikan oleh guru. Kelebihan dari model kooperatif tipe Numbered Head Together (NHT) yaitu setiap siswa menjadi siap semua, dapat melakukan diskusi dengan sungguh-sungguh, serta siswa yang pandai mengajari yang kurang pandai (Wijanarko, dkk, 2014, p.26).

Sesuai dengan observasi awal tentang hasil belajar siswa tahun 2015/2016 hanya mencapai 52\% (ketuntasan secara klasikal) yang belum mencapai standar minimal yaitu 65\%. Hal ini menjnjukkan bahwa siswa merasa sulit untuk memahami materi pelajaran Matematika yang ditunjukkan dengan rendahnya hasil belajar pada materi Pengukuran tentang Hubungan Antar Satuan Waktu, Panjang, Berat dan Satuan Kuantitas.

Kenyataan menunjukkan bahwa, penggunaan model mengajar yang tidak sesuai dengan materi yang diajarkan cenderung menghasilkan hasil belajar siswa kurang optimal, seperti yang dialami siswa IV SD Negeri 1 Puurau Kab. Kolaka Utara. Penyebab lain rendahnya hasil belajar siswa adalah perencanaan dan implementasi pembelajaran yang dilakukan oleh para guru pelajaran Matematika tampaknya masih dilandasi dengan metode transfer informasi. Kondisi pembelajaran seperti ini akan menimbulkan kebosanan bagi siswa, sehingga menyebabkan siswa hanya menerima pelajaran secara pasif.

Bertitik tolak dari uraian yang telah dipaparkan di atas, maka penulis mengadakan penelitian yang dirumuskan dalam suatu judul "Meningkatkan Hasil belajar siswa Siswa pada Materi Pengukuran Melalui Model Pembelajaran Kooperatif Tipe STAD di Kelas IV SD SD Negeri 1 Puurau Kab. Kolaka Utara".

Masalah dalam penelitian ini adalah: Apakah hasil belajar siswa pada materi pengukuran dapat ditingkatkan melalui model pembelajaran kooperatif tipe STAD di Kelas IV SD Negeri 1 Puurau Kab. Kolaka Utara? Tujuan penelitian ini adalah untuk meningkatkan hasil belajar siswa pada materi Pengukuran di Kelas IV SD Negeri 1 Puurau melalui model pembelajaran Kooperatif tipe STAD. Penelitian ini diharapkan dapat memberikan manfaat bagi guru, siswa, sekolah dan penelitian lainnya.

\section{Metode}

Jenis penelitian adalah penelitian tindakan kelas (PTK). Penelitian ini dilaksanakan pada semester ganjil tahun pelajaran 2016/2017 di IV SD Negeri 1 Puurau Kab. Kolaka Utara dengan Subyek dalam penelitian ini adalah iswa kelas IV SD Negeri 1 Puuraupada semester ganjil tahun ajaran 2016/2017 berjumlah 21 orang. Penelitian tindakan kelas ini dilaksanakan dalam dua siklus yang terdiri dari empat tahapan yaitu perencanaan, pelaksanaan tindakan, observasi dan evaluasi serta refleksi Jenis data dalam penelitian ini adalah data kualitatif dan kuantitatif. Data kualitatif berupa kegiatan proses pembelajaran aktivitas belajar siswa dan 
aktivitas guru. Data kuantitatif berupa nilai hasil belajar siswa. Sumber data dalam penelitian ini adalah guru dan siswa Kelas IV SD Negeri 1 Puurau Kab. Kolaka Utara.

Data kualitatif akan dianalisis secara deskriptif kualitatif berdasarkan observasi, sedangkan data kuantitatif dianalisis secara kuantitatif menggunakan rumus:

Indikator keberhasilan dalam penelitian ini adalah 1) Dari segi proses ketuntasan atau pelaksanaan pembelajaran dikatakan tuntas, bila rangkaian kegiatan-kegiatan telah mencapai minimal 80\% dilaksanakan. 2) Dari segi hasil, dikatakan tuntas minimal bila 80\% siswa telah mencapai nilai minimal 65

\section{Hasil}

\section{Hasil Belajar Siswa}

Hasil tes tindakan siklus I menunjukkan bahwa terjadi peningkatan hasil belajar siswa jika dibandingkan dengan evaluasi awal. Siswa yang memperoleh nilai $\geq 65$ sebanyak 12 orang $(57,14 \%)$, dengan nilai rata-rata 63,90. Walaupun hasil tes siklus I menunjukkan peningkatan tetapi karena belum mencapai KKM yang ditetapkan oleh pihak sekolah, maka penelitian ini dilanjutkan pada siklus II.

Berdasarkan analisis hasil tes siklus II bahwa pelaksanaan tindakan siklus II terjadi peningkatan sebesar 33,33\% atau sebanyak 7 orang siswa. Berikut tabel ketuntasan hasil tes belajar siswa:

\section{Aktivitas Guru}

Pada siklus I ketercapaian skenario pelaksanaan pembelajaran oleh guru pada pertemuan I adalah 55\% dan pertemuan kedua adalah 76,67\%. Pada siklus II, kertercapaian skenario pelaksanaan pembelajaran oleh guru pada pertemuan pertama adalah $80 \%$ dan pertemuan kedua adalah 93,33\%.

\section{Aktivitas Siswa}

Pada siklus ini aktivitas belajar siswa berdasarkan hasil pengamatan aktivitas belajar siswa diperoleh persentase ketercapaian pembelajaran pada pertemuan pertama adalah $53,57 \%$ dan pertemuan kedua adalah $73,21 \%$. Pada siklus II ini aktivitas belajar siswa berdasarkan hasil pengamatan aktivitas belajar siswa diperoleh persentase ketercapaian pembelajaran pada pertemuan pertama adalah 78,57\% dan pertemuan kedua adalah $92,85 \%$.

\section{Pembahasan}

Berdasarkan hasil observasi pada siklus I, guru dan siswa telah melakukan kegiatan pembelajaran melalui Model pembelajaran Kooperatif tipe STAD, Namun masih ada kekurangan-kekurangan, diantaranya pada saat memulai pembelajaran guru tidak menyampaikan tujuan pembelajaran yang hendak dicapai dan kurang memotivasi siswa sehingga siswa enggan untuk bertanya ketika mendapat kesulitan, siswa memilih diam karena segan untuk bertanya pada guru. Pada pertemuan I guru belum mampu mengorganisasikan waktu dengan baik. Hal ini terlihat dengan tidak terselesaikannya tes Quis yang telah dirancang. Pada siklus I ketercapaian skenario pelaksanaan pembelajaran oleh guru pada pertemuan I adalah 55\% dan pertemuan kedua adalah 76,67\%

Sementara itu pada pertemuan pertama siklus I masih ada siswa tidak memperhatikan penjelasan guru, belum memahami petunjuk pada LKS sehingga cenderung ribut dan bertanya terus, tidak aktif dalam bekerja, menyimpulkan hasil kerja kelompok masih kurang. Pada siklus ini aktivitas belajar siswa berdasarkan hasil pengamatan aktivitas belajar siswa diperoleh persentase ketercapaian pembelajaran pada pertemuan pertama adalah $53,57 \%$ dan pertemuan kedua adalah $73,21 \%$. 
Melihat kekurangan yang ada serta hasil belajar siswa pada materi pengukuran pada tindakan siklus I belum mencapai indikator keberhasilan maka peneliti melanjutkan tindakan siklus II. Hal-hal yang harus dilakukan pada siklus II adalah guru harus mendorong siswa agar lebih aktif dalam kegiatan pembelajaran melalui metode kerja kelompok, menelaah LKS dan menyimpulkan hasil kerja. Selain itu guru harus lebih memotivasi siswa untuk saling membantu dalam kelompok karena nilai kelompok ditentukan oleh nilai perkembangan semua anggota kelompok.

Untuk itu diawal pertemuan pada siklus II guru lebih membangun kerja sama tim pada setiap kelompok dengan harapan siswa akan lebih termotivasi bekerja sama dalam kelompoknya sehingga semua anggota kelompok memahami materi yang diberikan. Dengan diberikan penjelasan pentingnya keberhasilan bersama pada setiap kelompok maka keterlibatan semua anggota kelompok dalam menyelesaikan LKS yang diberikan oleh guru berdampak pada peningkatan nilai perkembangan masing-masing anggota kelompok. Disamping itu guru juga harus mampu mengelola waktu dengan efisien agar semua tahapan kegiatan dalam skenario pembelajaran dapat terlaksana dengan baik.

Pada evaluasi siklus II menunjukan peningkatan ketuntasan secara klasikal yaitu $90,47 \%$ atau sebanyak 19 orang siswa dengan perolehan nilai 76,57. Hal ini menunjukan peningkatan sebesar 33,33\% atau sebanyak 7 orang siswa bila dibandingkan dengan hasil evaluasi tindakan siklus I. Dengan demikian siswa yang mampu menunjukkan konsep tentang "pengukuran" semakin bertambah dibandingkan dengan evaluasi siklus I. Pada siklus II ini aktivitas belajar siswa berdasarkan hasil pengamatan aktivitas belajar siswa diperoleh persentase ketercapaian pembelajaran pada pertemuan pertama adalah $78,57 \%$ dan pertemuan kedua adalah $92,85 \%$. Pada siklus II, kertercapaian skenario pelaksanaan pembelajaran oleh guru pada pertemuan pertama adalah $80 \%$ dan pertemuan kedua adalah 93,33\%. Menurut Ibrahim dalam Santiana, dkk (2014, p.3) mengemukakan tiga tujuan yang hendak dicapai dalam pembelajaran kooperatif dengan tipe NHT yaitu:1) Hasil belajar akademik stuktural: Bertujuan untuk meningkatkan kinerja siswa dalam tugas-tugas akademik. 2) Pengakuan adanya keragaman: Bertujuan agar siswa dapat menerima temantemannya yang mempunyai berbagai latar belakang. 3) Pengembangan keterampilan sosial: Bertujuan untuk mengembangkan keterampilan sosial siswa.

Hasil belajar siswa ini mengindikasikan bahwa indikator yang ditetapkan telah tercapai. Sedangkan hasil obsevasi terhadap pelaksanaan pembelajaran boleh dikatakan sempurna, yakni seluruh komponen dalam skenario pembelajaran telah dilaksanakan dengan baik sesuai yang diharapkan. Karena kedua indikator telah tercapai, berarti Penelitian Tindakan Kelas dihentikan.

\section{Simpulan}

Berdasarkan hasil analisis dan pembahasan disimpulkan bahwa Model Pembelajaran Kooperatif tipe $S T A D$ dapat meningkatkan hasil belajar siswa siswa di Kelas IV SD Negeri 1 Puurau pada materi Pengukuran. Hal ini dapat dilihat dari hasil observasi awal ketuntasan secara klasikal yaitu 52\%. Pada tindakan siklus I ketuntasan secara klasikal meningkat menjadi $57,14 \%$ atau sebanyak 12 orang siswa dari 21 siswa dan pada siklus II terjadi peningkatan sebesar $90,47 \%$ atau 19 orang siswa. Dari segi proses pelaksanaan skenario pembelajaran yang dilaksanakan pada siklus I meningkat pada siklus II. 


\section{Referensi}

Arsini, Ni Nengah, Desak Putu Parmiti, \& Sumantri, Made. (2015). Pengaruh Model Pembelajaran Kooperatif Tipe Numbered Head Together (NHT) Terhadap Hasil Belajar IPS Siswa Kelas IV Semester II SD Gugus VI Kecamatan Kintamanitahun Pelajaran 2014/2015. e-Journal PGSD Universitas Pendidikan Ganesha Jurusan PGSD $\quad$ Vol: $\quad 3 \quad$ No: 1.10 . https://ejournal.undiksha.ac.id/index.php/JJPGSD/article/viewFile/5811/4200

Dewi, Fika. (2016). Pengaruh Model Pembelajaran Kooperatif Tipe Numbered Head Together Terhadap Hasil Belajar Siswa Pada Mata Pelajaran Matematika Kelas V SDN 1 Raman Endra Tahun Pelajaran 2015/2016. Skripsi. Fakultas Keguruan Dan Ilmu Pendidikan Universitas http://digilib.unila.ac.id/23873/3/SKRIPSI\%20TANPA\%20BAB\%20PEMBAHASA $\underline{\text { N.pdf }}$

Indah, Yurri Puspita. (2015). Kemampuan Pendekatan Open-Ended Terhadap Kemampuan Pemecahan Masalah Matematis dan Kemandirian Belajar Siswa SD pada Materi Pengukuran Panjang. Skripsi. Program Studi Pendidikan Guru Sekolah Dasar Universitas Pendidikan Indonesia. http://repository.upi.edu/19725/4/s_pgsd_kelas_1105183_chapter2.pdf

Mulyasa, E. (2009). Menjadi Guru Professional. Bandung: PT. Remaja Rosdakrya.

Permana, Erwin Putera. (2016). Penerapan Metode Pembelajaran Kooperatif Numbered Heads Together (NHT) Untuk Meningkatkan Hasil Belajar Dan Berpikir Kritis Siswa Pada Mata Pelajaran IPS SD. Jurnal Pendidikan Dasar Nusantara Volume 1, Nomor 2. 49-58. http://ojs.unpkediri.ac.id/index.php/pgsd/article/view/210

Santiana, Ni Luh Putu Murtita, Dewa Nyoman Sudana \& Garminah, Ni Nyoman. (2014). Pengaruh Model Pembelajaran Kooperatif Tipe Numbered Heads Together (NHT) Terhadap Hasil Belajar Matematika Siswa Kelas V Sekolah Dasar Di Desa Alasangker. Jurusan PGSD Vol. 2 No. $1.1-10$. https://ejournal.undiksha.ac.id/index.php/JJPGSD/article/view/3232

Suhardi, Marungkil Pasaribu, \& Nuryanti, Siti. (2014). Penerapan Model Pembelajaran Kooperatif Tipe Numbered Head Together (NHT) Untuk Meningkatkan Hasil Belajar Siswa Pada Mata Pelajaran IPA Kelas IV SD Negeri 3 Tondo. Elementary School of Education E-Journal, Media Publikasi Ilmiah Prodi PGSD Vol 2, Nomor 2. 26-33. http://jurnal.untad.ac.id/jurnal/index.php/ESE/article/view/2824

Suparno P. (2008). Riset Tindakan untuk Pendidik. Jakarta: Grasindo.

Wijanarko, PD, Sukarjo \& Purnomo. (2014). Numbered Head Together Berbantuan Media Visual Untuk Meningkatkan Kualitas Pembelajaran PKn. Joyful Learning Journal 3 (1). 24-30. https://journal.unnes.ac.id/sju/index.php/jlj/article/view/5893/4602 